EIS $14 / 2020$

Exploring Tendencies in Migrants' Legal

Consciousness

Research and

Uncovering Factors For

Socio-Legal Integration

Submitted 06/2020

Accepted for publication $08 / 2020$

\section{Exploring Tendencies in Migrants' Legal Consciousness Research and Uncovering Factors for Socio-Legal Integration}

\author{
Ramuné Miežanskienè
}

Kaunas University of Technology

$\Gamma$ Crossef http://dx.doi.org/10.5755/j01.eis.1.14.26774

The current state of scientific discourse on legal consciousness occurs within a range of topics of enquiry. In this scope of research, a trendline of publications emerged which employs a narrower focus on the aspects of migrants' legal consciousness. As there were no systematic research aspirations in this particular field, this research explores the current scientific discourse, addresses factors for sociolegal integration and uncovers further paths for scientific enquiry as well. The following investigation adopts a method of systematic literature review which covers the time frame of research of three decades - since 1990 and introduces the main tendencies in scientific research on migrants' legal consciousness. It addresses their geographical spectrum and particular reasoning that leads to scientific research. The other task was set to highlight the main factors which were identified to be affecting migrant's legal consciousness and socio-legal integration as equally. The results of the investigation revealed a relatively small, but growing body of literature exploring migrants' legal consciousness with a considerably narrow geographical division of the research, concentrating mainly to one continent, and with a dominant focus to national (versus comparative) context. Therefore the current field of scientific literature on migrants' legal consciousness could benefit from the dissemination of investigations in the varied cultural environments and legal systems, as well as launching comparative studies while addressing a varying legal status. This research indicates a range of factors which plays a role in shaping migrants' consciousness, though few of them come into frontline while referring different migrants' legal status. These include, but are not limited to the list, covering legal framework and social norms or ideals of the host country, as well as the encounter with the institutional sector and cultural heritage.

KEYWORDS: legal consciousness, migration, integration, legal culture.

The trendline in socio-legal studies has been marked by a profound and constantly evolving body of literature which is featured by a variety of theoretical and empirical frameworks (Creutzfeldt et al., 2019). While navigating in this field, comprehensive scholars' attention was dedicated to individuals relationship with law and the studies of the considerably flexible paradigm of legal consciousness (L.J. Chua \& Engel, 2019). Alongside the response to migration-related challenges in society, the attention to migrant's legal consciousness research had been also a part of this field of interest. In a broader context, addressing migrant's relation to the host country's legalities means addressing migrant's integration process in a certain angle (Leisy J. Abrego \& Lakhani, 2015; Agnieszka Kubal, 2009; Waldrauch \& Hofinger, 1997) which in turn serves in providing insights how to mitigate very often challenging migrant's transition to a new socio-legal environment.

The current state of scientific discourse on legal consciousness occurs in different topics, ranging from but not limited to individual's relation with justice system' institutions as courts or police 
(Farmer et al., 2015; Feng \& He, 2018; Khorakiwala, 2018; Klambauer, 2018; Pennington, 2015; Tarasov, 2015), exploited in the employment relationship (Blackstone et al., 2009; Casebeer, 2008; Kirk et al., 2017; Marshall, 2005), dedicated to family life-related aspects (De Hart \& Besselsen, 2020; Liu, 2018; Wang, 2019) or education (Egorov \& Umnyashova, 2017; Huang, 2016; Ma, 2018). The field of research in legal consciousness has also been well theoretically and methodologically grounded by profound scholars as Leisy J. Abrego, Simon Halliday, Lynette J. Chua, David M. Engel, Marc Hertogh and others who have represented narratives and theories ranging from North America to Europe. If to address the last decades of the research field in legal consciousness, there could be noticed a sprung of the diversity of investigations. A considerably large number of research aspirations come in line with a narrower focus to the particular aspects of legal consciousness referring to gender (Bendall \& Harding, 2018; Digregorio, 2016; Park et al., 2016), religion (Arsenovich et al., 2019; Barak-Corren, 2017), migration or minority aspects (S. Gleeson, 2010; Graca, 2018; Ho \& Chua, 2016). The branching of the research area has also led to more elaborate reviews regards the researches on legal consciousness. Therefore, after more than a decade after the introduction of the concept of legal consciousness to the migration research field, there comes a need to overview the scientific input and to consider what the following applications or the prospects of this line of research could be. Following this, this paper aims to explore and introduce the scope and tendencies in research dedicated to migrant's legal consciousness while using a systematic literature review.

The primary need for systematic literature review lies in the demand for more elaboration and distinctiveness in scientific discussion, considering the major trends underlying in this field of research. As it is already mentioned, it also contributes to following up and highlighting the trendline of research over a longer period in scientific discourse in the larger spectrum of legal consciousness research. Therefore, this paper is targeting to introduce and fill the gap in legal consciousness researches as there was no particular scientific aspiration to present the topic using a method of systematic literature review. In this way, the following research will present a constituent step forward in scientific knowledge in this sub-field of legal consciousness research. The main tasks of the investigation were set to:

1 introduce the tendencies of scientific research, dedicated to exploring migrants' legal consciousness in the time frame of three decades (1990 - 2020);

2 explore the spectrum of migrant's legal consciousness research referring to the range of geographical research distribution and concentration;

3 present the main consolidated factors which were identified to be affecting migrants' legal consciousness.

The beforementioned tasks were addressed by comprising two sets of publications whereas the detailed procedure of selection is explained further on in the methodology paragraph.

\section{Methodology}

While seeking to address the topic comprehensively the research employed a systemic literature review method to identify a set of relevant publications for further exploration. The particular method was chosen as a suitable framework which allows gathering information in a structured way to present research of particular interest.

The selection procedure for the publications was conducted in three stages: 1) identification, 2) selection and exclusion of records, and 3) assessment for eligibility and conclusion of two samples for further investigation of publications.

While seeking to identify the scope of literature, which was dedicated to legal consciousness, the initial search has addressed three of the world's leading search engines with a vast coverage of 
Figure 1

Selection procedure for the publications to be reviewed (produced by the author, 2020)

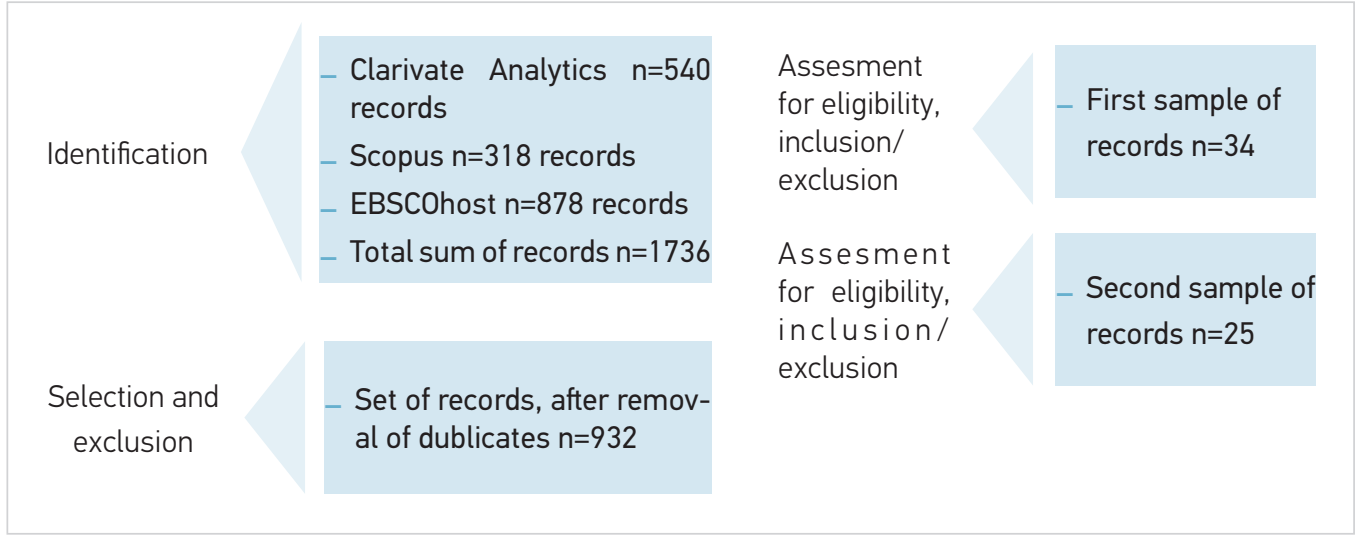

social science research: Clarivate Analytics, Scopus and EBSCOhost. The chosen databases encompass a wide range of disciplines, topics and thematical range for socio-legal studies as well. The following systematic review has addressed publications within a time frame from January of 1990 to April of 2020 which covers a time range of three decades.

The search was conducted using keywords "legal consciousness" to directly address the theoretical framework of legal consciousness as it is covering individual's relation to law, and do not diverge the search to addressing the spheres of legal culture or legal systems. To obtain a comprehensive search of scientific literature the key-term was not narrowed to the search only in publications' titles, but also included the content of abstracts and key wors of scientific production in the following type of sources: academic articles, books, conference materials and dissertations. The broadened range of search allowed to identify studies, where the theory of legal consciousness was not used as the leading one, but the research object addressed the conceptual frame of "legal consciousness“, for example, race or gender theories. The data gathering has been conducted in April and May of 2020, which resulted in the identification of 1736 records (Initial stage). At the second stage, the duplicates were removed and the number of 932 publications for the review was identified. Though in the second stage the content of the publications was not challenged by questioning whether the articles were investigating legal consciousness as a primary research aim or just as a part of the context. This was done in the third stage, where publications were coded using the software package for qualitative and mixed methods research -"Maxqda". At this stage, publications were coded according to the main inclusion/exclusion criteria - whether publication addressed the topic of migrant's legal consciousness. During the selection and exclusion stage, there was also a standard form used to code publications with the following codes while identifying: a) the general characteristics of the publication (authors' identity, year and type of the publication (b) characteristics of research (methods for data collection and their combinations, geographical region that study has covered).

For the analytical purposes that would correspond to the tasks, two sets of samples were designed. The first two tasks that aim at introducing the spectrum and tendencies of research the sample no. 1 consisted of 34 publications. For deeper analysis which is required for the third task to be completed, the second sample was developed in accordance to these inclusion/exclusion criteria: a) the possibility to access the full version of publication; b) the paper presented and elaborated data of original research; c) empirical investigation was conducted and introduced to scientific discourse. After this procedure, the second sample encompassed 25 articles.

The key results of the conducted research revealed that more than half of publications addressing migrants' legal consciousness originates from one continent and nearly all of them were dedicated to explore national contexts. A considerably narrow geographical division of publications implicates 
a gap and a possibility of scientific aspirations on migrant's legal consciousness in other cultural settings as well as the possibility for comparative research. The current main body of literature is concentrated on a set of few countries and narratives where the interest of researching particular migrant groups (as undocumented migrants) prevails. Therefore the current scope of research of scientific literature on migrants' legal consciousness could benefit from the dissemination of investigations in the varied cultural environments and legal systems, also gain from the inclusion of migrants' with varying legal status, as well as launching comparative studies.

While exploring the main factors which informs legal consciousness and in this way produces input to socio-legal integration this research found that migrant's legal status gave rise to put different aspects into the spotlight. In a case of undocumented migrants' situation, the prevailing factor which informs and obtains a power to shift legal consciousness was situated in the legal framework of the host country as well as particular social norms and ideals of the host country too (to be precise - meritocracy in the USA). If to refer to the factors shaping detained and asylum seekers' legal consciousness, the encounter with an institutional sector and immigration officials was introduced to be the main driver. The field of cultural heritage and disadvantageous positions in certain structures (a case of employment) was indicated to be one of the leading factors to impact to documented migrants' legal consciousness. Though it also has to be taken to the account that the limitations of this research provide insights but do not allow to generalize these findings, because of a lack of broader scope of research in varying cultural surroundings.

During recent decades, socio-legal studies have attracted scholars' attention which had its impact on the research of legal consciousness as well. The review of academic publications since 1990 (932 in total up to April of 2020) indicate a high number of studies, adopting the concept of legal consciousness which has been increasing since 2001 and shows an acceleration from 2015 to 2018 (see: figure 1.). There could be also noticed that these studies have drawn more of scholars' attention around the same time as the topic of migrants' legal consciousness has launched. In general, the spectrum of publications on migrant's legal consciousness has been covered from 2004 (see. figure 2.).

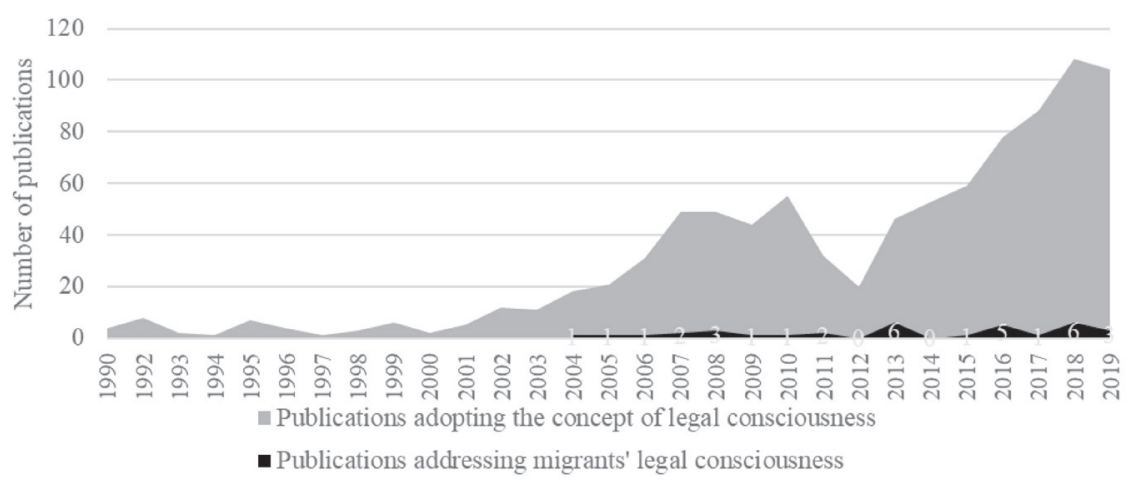

While accurately addressing these numbers there should be also noticed, that the overall interest in the topic of migrants' relation to the host countries' law could not be generalized by the frequency of research only looking through the lens of the concept of migrants' legal consciousness. Due to the usage of different concepts and variety of interest in the field, there are other studies which methodologically might be leading to a different platform of scientific interest while exploring migrants relation to host country's legalities, legal system or institutions. In these cases the scientific enquiry or insights might be overlapping, but not the theoretical approach. While addressing literature on
Tendencies and features of research on migrants' legal consciousness

\section{Figure 2}

A trend of publications, adopting a concept of legal consciousness and addressing migrant's legal consciousness (produced by the author, 2020) 
undocumented migrants' situation Emily Ryo has identified at least two bodies of research that examine legal consciousness: one is focusing on how individuals understand their illegality and the impact of those understandings on their identity formation, legal mobilization, and integration. The second body of research "focuses more directly on evaluative judgements that immigrants make about the law and legal authority, intending to understand the nature and determinants of those attitudes, and their effects on cooperation or compliance with legal authority“ (Ryo, 2017, p. 107). Therefore, migrants' relation to the host countries' law (in a broad sense) might be reflected using other concepts as „,egal attitudes“, „crimmigration“, „,rights consciousness“ which presents a related, but also a different angle of view. Considering given, this research is focusing on the conceptual framework of legal consciousness mainly because of a grounding reason - the methodological framework of legal consciousness. It (mostly) covers not a particular, but a complexity of lear of phenomena which in turn produces a comprehensive scientific approach. As J. Chua and David M. Engel notice, "legal consciousness does not simply refer to legal awareness, nor is it meant to measure knowledge_or ignorance_of the law" it is the ways in which people experience, understand, and act in relation to law (L.J. Chua \& Engel, 2019, p. 336). On the other hand, scholars admit, that the field of legal consciousness literature is not considered to be monolithic as well. While addressing the scope of legal consciousness studies the same Lynette J. Chua and David M. Engel research reveals that there is no unanimous theoretical approach of the application of legal consciousness theory. Their exploration results in naming three different schools - „Identity, Hegemony, and Mobilization" where researchers admitted to pursue different goals and deploy the concept of legal consciousness in different ways. Nonetheless, the theoretical framework of legal consciousness stands on a common ground of subjectivity as individuals' understandings, interpretations and responses (Lynette J. Chua \& Engel, 2019). This, in turn, provides a substantial background and presumable methodology for further exploration.

If to address the main features of scientific discourse on migrant's legal consciousness, it might raise a few considerations about their locality and concentration. While investigating those publications which explores migrant's legal consciousness at a closer range (sample no. 1), we find a great part of them concentrated on a national level (94\%) and stemming mainly from one continent - North America (61.76 \%) (see figure no 3 and 4).

Figure 3

Geographical distribution of publications dedicated to migrant's legal consciousness (produced by the author, 2020)

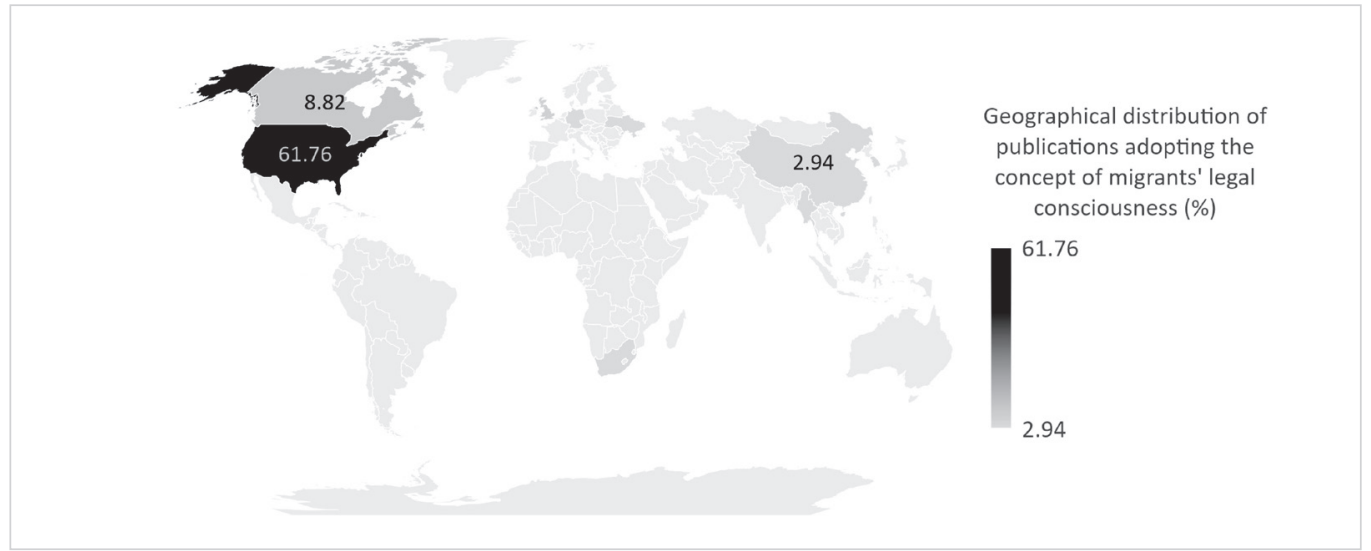

While scholars' provide grounding for research, there could be identified at least two types of rationale in the background in terms of research locality. One of them would constitute a need to address a certain (in this case marginalizing) aspect of social life - challenges related to migrants' situation as restrictive policies that placed irregular migrants in precarious situations (Tungohan, 2018) or challenges associated with low-wage work and the particular vulnerability of immigrant workers (S. Gleeson, 2010). The second aspiration for research would constitute the theoretical 
aspirations which focus on scientific enquiries. Why migrants act, how they act and why they do, what they do? This corresponds to a more than one school of legal consciousness that framed as „Identity, Hegemony, and Mobilization“. For example, L. Albrego reveals aspects of new rights-granting law immigrants' claims-making behaviour while addressing social construction of first and 1.5 generation undocumented immigrants (Leisy Abrego, 2008; Leisy J. Abrego, 2011). We might also find the question how (and why not) migrants mobilize law. This is portrayed in the research of X. He, L. Wang and Y. Su by addressing the question of why migrant workers choose disruptive actions over legal ones (Xin He et al., 2013).

The before mentioned concentration of studies on migrant's legal consciousness could be partially explained by overviewing the location of main diasporas of migrants around the world as this could to some extent indicate the emergence of the topic. The World Migration Report 2020 provides a list of twenty countries, hosting the largest numbers of international migrants (see figure 5) throughout the three decades (the same time frame as this research is addressing). There could be indicated that 34 publications that focus on migrant's legal consciousness fall into the list of just nine countries: USA, Canada, United Kingdom, China, Myanmar, Germany, South Africa, Ukraine, South Corea (see figure no. 5) There are only two which are relatively small in number in terms of publications and were not indicated to be in the list (hosting the largest numbers of international migrants in the United Nations' list). These are South Corea and Myanmar. As the number of migrants in the host country seems to be explaining the scientific interest in their relation to welcoming country's legal system, but it does not explain extremely low levels of scientific interest in other countries which also welcomes a large number of migrants (Russia, India, Saudi Arabia etc.). In this case, the scholarly interest could be partially affected by the general trendline of the migrants' related state policy in the welcoming country.

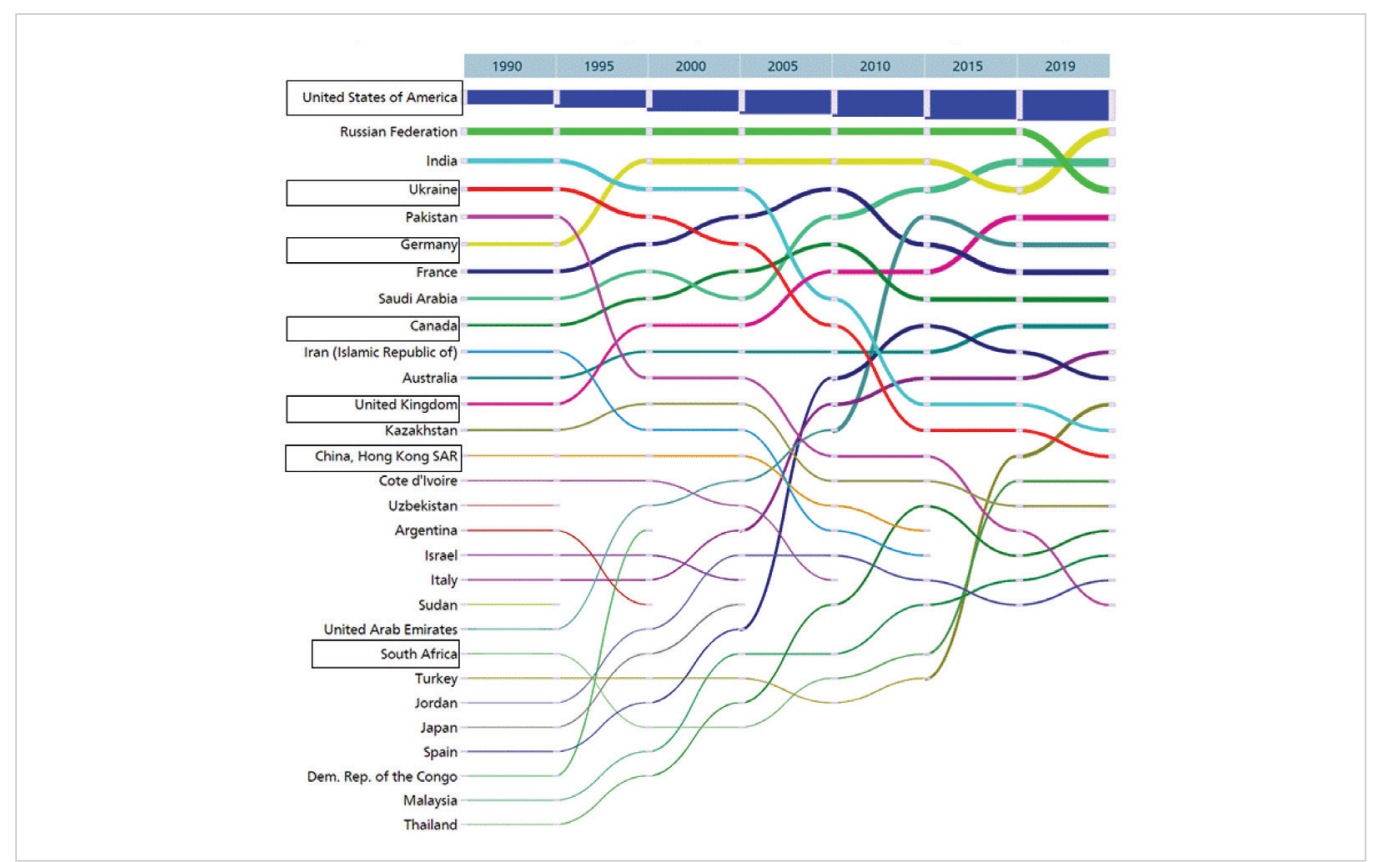

\section{Figure 4}

Levels of geographical research inquiry addressing migrant's legal consciousness (produced by the author, 2020)

Figure 5

Twenty countries or areas hosting the largest numbers of international migrants (millions) United Nations Department of Economic and Social Affairs, 2020 
If to go further in asking what would be scientific aspirations for migrant's legal consciousness research, we would find questioning what triggers the rise of this particular theoretical approach? If to assume that the problem in society has given rise to the topic, it barely explains the current locality of migrants legal consciousness research coverage. For example, both of the continents of Europe and North America have experienced challenges related to migration. Though they were vastly introduced to the European society's debate since 2014 (Berry et al., 2015), it did not result in the trend of research, dedicated to migrant's legal consciousness in Europe (Figure 3). As there could be noticed once again, a considerable part of research on migrants' legal consciousness is allocated in North America (see. Figure 3 ). An enquiry comes into forth whether this is an influence of a profound theoretical school which is set up regionally, and/ or theory applicability related to the conceptual socio-legal framework deriving from differences of legal systems or generally - legal culture. This question provides an additional stimulus for further scientific investigations.

The considerably narrow geographical division of the research production might implicate few assumptions: firstly, the indication, on one prevailing theory and methodology as well as a circle of leading scholars (further addressed in the next section) in this spectrum of research. Secondly, the gap of scientific knowledge about migrant's experiences in other countries and cultural settings that have not been addressed yet.

Addressing

features of migrants' legal consciousness and factors which informs it
By following the general overview of empirical investigations which address migrant's legal consciousness, we would find them conducted and spread throughout just more than a decade (since 2005). While trying to fulfil the third task of this research, the attention will be paid to the main features of legal consciousness and factors which informs it. In this section, the results of original empirical research from 25 publications will be examined (see the second sample - table 1 and 2).

To be precise regards scientific insights on migrants' legal consciousness it is important to address the legal status of the target group of migrants/interviewees and respondents, which have participated in particular empirical researches. As is discussed before, the immigration status is considered to play a major role in affecting migrant's legal consciousness. For example, S. Gleeson highlights that immigration status might be affecting the legal consciousness of immigrant workers in their approach to claims-making (Shannon Gleeson, 2010, p. 563). The second sample has addressed a range of legal statuses of migrants' in welcoming society: official residents - employees, undocumented migrants, asylum seekers, detainees or even re-emigrants. Therefore, beforementioned variety implicates a visible diversity in the scope of the results of research. There should be mentioned that more than $2 / 3$ of research in a sample had been addressing undocumented/irregular status of migrants' and, like in a previous sample (no.1), the continent of North America dominates by investigating a particular cultural and sociolegal context of two countries (the USA and Canada).

The leading scholar's role in this set of research is performed by L. J. Abrego encompassing investigations focused on the topic of undocumented migrants (Deferred Action for Childhood Arrivals (DACA) recipients and their families' situation (Abrego, 2008, 2011, 2018, 2019). The same context was also explored by other empirical research in the sample (Farrell-Bryan, 2016; Swan \& Clark-Ibáñez, 2017). A relatively small number of investigators indicates about strong leadership in the particular trendline of research focused on undocumented migrants. Far less attention was dedicated to the exploration of regular migrants' legal consciousness and factors which informs it. Considering the latter segment, there is no particular country of dominance or leading scholars role. 


\begin{tabular}{|c|c|c|c|}
\hline No. & Author(s) & Year & Title of the publication \\
\hline 1. & L. J. Abrego & 2008 & $\begin{array}{l}\text { Legitimacy, Social Identity, and the Mobilization of Law: The Effects of } \\
\text { Assembly Bill } 540 \text { on Undocumented Students in California }\end{array}$ \\
\hline 2. & L. J. Abrego & 2011 & $\begin{array}{l}\text { Legal Consciousness of Undocumented Latinos: Fear and Stigma as } \\
\text { Barriers to Claims-Making for First- and 1.5-Generation Immigrants }\end{array}$ \\
\hline 3. & L. J. Abrego & 2018 & $\begin{array}{l}\text { Renewed optimism and spatial mobility: Legal consciousness of Latino } \\
\text { Deferred Action for Childhood Arrivals recipients and their families in Los } \\
\text { Angeles }\end{array}$ \\
\hline 4. & L. J. Abrego & 2019 & $\begin{array}{l}\text { Relational Legal Consciousness of U.S. Citizenship: Privilege, } \\
\text { Responsibility, Guilt, and Love in Latino Mixed-Status Families. Law and } \\
\text { Society Review }\end{array}$ \\
\hline 5. & K. M. Casebeer & 2008 & $\begin{array}{l}\text { Of service workers, contracting out, joint employment, legal } \\
\text { consciousness, and the University of Miami }\end{array}$ \\
\hline 6. & $\begin{array}{l}\text { T. DoCarmo, R. } \\
\text { Rosales }\end{array}$ & 2019 & $\begin{array}{l}\text { Legal Consciousness Among Asylum Seeking Immigrants in the US: From } \\
\text { Expectations of Fairness to Increasing Legal Cynicism }\end{array}$ \\
\hline 7. & D. Farrell-Bryan & 2016 & $\begin{array}{l}\text { Immigrant Youth, Social Identity, Instability: Legal Consciousness and the } \\
\text { Effects of Deferred Action for Childhood Arrivals }\end{array}$ \\
\hline 8. & A. García & 2016 & $\begin{array}{l}\text { Local Laws and Undocumented Mexicans' Political Engagement: Why } \\
\text { Immigrant Destinations Matter }\end{array}$ \\
\hline 9. & S. Gleeson & 2010 & $\begin{array}{l}\text { Labor Rights for All? The Role of Undocumented Immigrant Status for } \\
\text { Worker Claims Making }\end{array}$ \\
\hline 10. & L. Macia. & 2016 & Experiences of Discrimination in an Emerging Latina/o Community \\
\hline 11. & C. Menjívar & 2011 & $\begin{array}{l}\text { The power of the law: Central Americans' legality and everyday life in } \\
\text { Phoenix, Arizona }\end{array}$ \\
\hline 12. & S. M. Muñoz & 2016 & $\begin{array}{l}\text { Undocumented and unafraid: Understanding the disclosure management } \\
\text { process for undocumented college students and graduates }\end{array}$ \\
\hline 13. & S. M. Muñoz & 2018 & $\begin{array}{l}\text { Unpacking Legality Through La Facultad and Cultural Citizenship: Critical } \\
\text { and Legal Consciousness Formation for Politicized Latinx Undocumented } \\
\text { Youth Activists }\end{array}$ \\
\hline 14. & $\begin{array}{c}\text { C. E. Santos, C. } \\
\text { Menjívar, R. A. } \\
\text { VanDaalen, O. } \\
\text { Kornienko, K. A. } \\
\text { Updegraff, S. Cruz }\end{array}$ & 2018 & $\begin{array}{l}\text { Awareness of Arizona's immigration law SB1070 predicts classroom } \\
\text { behavioural problems among Latino youths during early adolescence }\end{array}$ \\
\hline 15. & A.A. Smith & 2005 & $\begin{array}{l}\text { Legal Consciousness and Resistance in Caribbean Seasonal Agricultural } \\
\text { Workers* }\end{array}$ \\
\hline 16. & $\begin{array}{l}\text { R. S. Swan, M. } \\
\text { Clark-lbáñez }\end{array}$ & 2017 & $\begin{array}{l}\text { Perceptions of Shifting Legal Ground: Daca and the Legal Consciousness } \\
\text { of Undocumented Students and Graduate }\end{array}$ \\
\hline 17. & E. Tungohan & 2018 & $\begin{array}{l}\text { Living with Compromised Legal Status: Irregular Temporary Foreign } \\
\text { Workers in Alberta and the Importance of Imagining, Strategizing, and } \\
\text { Inter-Provincial Legal Consciousness* }\end{array}$ \\
\hline 18. & P. K. Virdi. & 2013 & Barriers to Canadian justice: immigrant Sikh women and izzat* \\
\hline
\end{tabular}

Table 1

Publications representing the context of North America (USA and Canada*)/comprising the second sample

Source: produced by the author, 2020 
Table 2

Publications representing the context of countries from Africa, Europe and Asia / comprising the second sample

\begin{tabular}{|c|c|c|c|}
\hline No. & Author(s) & Year & Title of the publication \\
\hline 19. & S. Graca & 2018 & $\begin{array}{l}\text { Portuguese culture and legal consciousness: A discussion of } \\
\text { immigrant women's perceptions of and reactions to domestic } \\
\text { violence }\end{array}$ \\
\hline 20. & X. Wang He, L.Y. Su & 2013 & $\begin{array}{l}\text { Above the roof, beneath the law: Perceived justice behind } \\
\text { disruptive tactics of migrant wage claimants in China }\end{array}$ \\
\hline 21. & E. L. E. Ho, L.J. Chua & 2016 & $\begin{array}{l}\text { Law and 'race' in the citizenship spaces of Myanmar: spatial } \\
\text { strategies and the political subjectivity of the Burmese Chinese }\end{array}$ \\
\hline 22. & A. Kubal & 2015 & $\begin{array}{l}\text { Legal consciousness as a form of social remittance? Studying } \\
\text { return migrants' everyday practices of legality in Ukraine }\end{array}$ \\
\hline 23. & T. Masiangoako & 2018 & Rationalising injustice \\
\hline 24 & H. Schwenken & 2013 & $\begin{array}{l}\text { "The EU Should Talk to Germany" Transnational Legal Consciousness } \\
\text { as a Rights Claiming Tool among Undocumented Migrants }\end{array}$ \\
\hline 25. & S. Singer & 2019 & $\begin{array}{l}\text { "Desert Island" detention: Detainees' understandings of "Law" in } \\
\text { the UK's immigration detention system }\end{array}$ \\
\hline
\end{tabular}

Source: produced by the author, 2020

While trying to answer the question what are the main factors informing migrant's legal consciousness and what features of legal consciousness it might bring forward the researchers addressed a broad contextual framework, ranging from evaluating cultural background (P.K. Virdi, 2013), restrictive policies and legal framework (A.A. Smith, 2005; Tungohan, 2018), societal views (Swan \& Clark-lbáñez, 2017), institutional interaction (DoCarmo \& Rosales, 2019) and welcoming countries' social norms and ideals (L. Abrego, 2008; Farrell-Bryan, 2016). Though applying a lense of migrants' legal status, few factors come into the front line.

Research exploring the legal consciousness of undocumented migrants reveals that the role of the legal framework of a welcoming country is of primary importance. While exploring legal consciousness of migrant youth in USA Richelle S. Swan and M. Clark-Ibáñez notices that after initiation of the deferred status policy for childhood arrivals, which have granted at least a temporary, but legal status of residency, „,perceptions of the legal system, its various symbols, and its actors changed significantly“(Swan \& Clark-Ibáñez, 2017, p. 82). L. Albrego research also confirms the power to shift legal status by the mean of the legal framework. It is revealed that through particular legal regulation migrant students were able to reposition themselves and „shift legal consciousness from being against the law to being with the law-able to mobilize the law by using it as a resource in their favor" (Leisy Abrego, 2008, p. 729). Even more, while exploring how youth make sense of laws and how laws affect their socio-emotional development E. Santos notices, that awareness itself about strict immigration laws "can impact their educational and psychological prospects, and even their friendships and relationships"(Santos et al., 2018, p. 1673). A verifying assumption comes from S. A. García's research which reveals that the design of local immigration laws profoundly shapes the nature of democratic participation for marginalized immigrant groups (García, 2016). Though E. Tungohan in his investigation on irregular migrants' situation argues, that the presence of restrictive policies that place irregular migrants in precarious situations do not create a uniformly chilling effect on their actions and their life choices (Tungohan, 2018, p. 207). If to address the features, of undocumented migrant's legal consciousness D. Farrell-Bryan mentions the aspect of meritocracy which comes into forth 
(a meritocratic legal consciousness by which migrants must prove their deservingness) which was also identified by L. Albrego (Leisy Abrego, 2008; Farrell-Bryan, 2016). Finally, E. Tungohan notices a ,developing inter-provincial legal consciousness requiring migrants to actively develop an awareness of legal norms - claim rights for themselves" (Tungohan, 2018, p. 208).

The examination on what might be the key factors that affect detainees and asylum seekers ' legal consciousness brings into spotlight the initial encounter with institutions of a welcoming country. The might be portrayed as a part of an „inaccessible system“ (Singer, 2019) or having a credit of respect witch tend to shift to cynicism throughout the detention process (DoCarmo \& Rosales, 2019). While approaching detainees situation S. Singer finds differing modes of legal consciousness featuring law as an oppositional force to be battled against or avoided, but also a system of rules which can be manipulated with the requisite access to knowledge and resources (Singer, 2019, p. 28).

Researchers dedicating their attention to migrants, having the legal residency (or navigating in between) in the host country where focusing to employment (Casebeer, 2008; X. He et al., 2013; Adrian A. Smith, 2005; Tungohan, 2018), violence against women (Graca, 2018; Preet Kaur Virdi, 2013) or migrants' social remittance (A. Kubal, 2015). A. A. Smith pays attention to the relationship between legal knowledge and the successful assertion of legal rights, which might be complicated by an individual's understanding of law's utility (A.A. Smith, 2005, p. 105). X. Wang He, L.Y. Su indicates that migrant workers' perception of justice is shaped by their disadvantaged status as well as political and business elite (Xin He et al., 2013). E. L. E. Ho and L.J. Chua investigate people's negotiations with the law in political-legal regimes that do not subscribe to liberal democratic norms. Their research explores how Burmese Chinese deploy to navigate oppressive laws and in this particular context legal consciousness is characterized by vulnerability under the rule of an ethnocratic state (Ho \& Chua, 2016). The role of cultural capital is also highly important in migrants' legal consciousness research as well and is stated to be one of the factors to inform it (P.K. Virdi, 2013).

While overviewing the results of the empirical research we find a range of factors which play a role in shaping and shifting migrants' legal consciousness. As it is noticed that different factors come into the spotlight while referring to the legal status of newcomers in a host country, it might imply a differentiation of interaction with a host country' law. In simple terms - addressing the legal framework it provides to migrants and setting up different measures to mitigate the challenges in relation to the host countries law accordingly.

1 The investigation on the tendencies on migrants' legal consciousness research reveals a considerably narrow geographical division and contextual locality of publications. More than half of them originates from one continent (North America) and nearly all are dedicated to explore and refer to national contexts. A considerably narrow geographical division of publications implicates a gap and a possibility at the same time for further scientific enquiry on migrant's legal consciousness. The researchers' aspirations could lead to other cultural settings providing insights for the comparative approach on migrants' legal consciousness as well as provide additional knowledge about migrants' socio-legal integration processes.

2 There could be noticed a range of main factors which were indicated to inform migrants' legal consciousness in terms of the context of their legal status. In the case of undocumented migrants' situation, the prevailing factor which informs and obtains a power to shift legal consciousness was observed to be the legal framework of the host country alongside with restrictive immigration measures. The other, but nevertheless important aspect considered to be the particular social norms and ideals of the host country. While referring to the factors playing a role in shaping detained and asylum seekers' legal consciousness, the encounter 
with an institutional sector and immigration officials were introduced to be as the leading drivers to affect legal consciousness, including their power to participate as a push factor for changes towards legal cynicism. The aspect of cultural heritage and disadvantageous positions in particular employment structures were indicated to be those highlighted factors that were addressed by scholars and identified to play a role while investigating documented migrants' legal consciousness.

References

Abrego, L. (2008). Legitimacy, social identity, and the mobilization of law: The effects of assembly bill 540 on undocumented students in California. Law and Social Inquiry, 33(3), 709-734. https://doi.org/10.1111/j.17474469.2008.00119.x

Abrego, L.J. (2011). Legal Consciousness of Undocumented Latinos: Fear and Stigma as Barriers to Claims-Making for First- and 1.5-Generation Immigrants. Law and Society Review, 45(2), 337-370. https://doi.org/10.1111/j.1540-5893.2011.00435.x

Abrego, L.J. (2018). Renewed optimism and spatial mobility: Legal consciousness of Latino Deferred Action for Childhood Arrivals recipients and their families in Los Angeles. Ethnicities, 18(2), 192-207. https://doi. org/10.1177/1468796817752563

Abrego, L.J. (2019). Relational Legal Consciousness of U.S. Citizenship: Privilege, Responsibility, Guilt, and Love in Latino Mixed-Status Families. Law and Society Review, 53(3), 641-670. https://doi.org/10.1111/ lasr.12414

Abrego, Leisy. (2008). Legitimacy, Social Identity, and the Mobilization of Law: The Effects of Assembly Bill 540 on Undocumented Students in California. Law \& Social Inquiry, 33(3), 709-734. https://doi.org/10.1111/ j.1747-4469.2008.00119.x

Abrego, Leisy J. (2011). Legal Consciousness of Undocumented Latinos: Fear and Stigma as Barriers to Claims-Making for First- and 1.5-Generation Immigrants. Law and Society Review, 45(2), 337-370. https://doi.org/10.1111/j.1540-5893.2011.00435.x

Abrego, Leisy J., \& Lakhani, S. M. (2015). Incomplete Inclusion: Legal Violence and Immigrants in Liminal Legal Statuses. Law and Policy, 37(4), 265-293. https:// doi.org/10.1111/lapo.12039

Arsenovich, R. Y., Abdurazakov, A. A., Abolmasova, T. E., Kuchenev, A. V., \& Khvan, T. S. (2019). The convergence of religious legal consciousness in the context of global migration processes. Journal of Law, Religion and State, 7(3), 337-364. https://doi. org/10.1163/22124810-00703004

Barak-Corren, N. (2017). Beyond dissent and compliance: Religious decision makers and secular law. Ox- ford Journal of Law and Religion, 6(2), 293-322. https:// doi.org/10.1093/ojlr/rwx002

Bendall, C., \& Harding, R. (2018). Heteronormativity in dissolution proceedings: Exploring the impact of recourse to legal advice in same-sex relationship breakdown. Philosophical Foundations of Children's and Family Law, 134-152. https://doi.org/10.1093/ oso/9780198786429.003.0007

Berry, M., Garcia-Blanco, I., \& Moore, K. (2015). Press Coverage of the Refugee and Migrant Crisis in the EU: A Content Analysis of Five European Countries. In United Nations High Commission for Refugees. http://arxiv. org/abs/quant-ph/0307179

Blackstone, A., Uggen, C., \& McLaughlin, H. (2009). Legal consciousness and responses to sexual harassment. Law and Society Review, 43(3), 631-668. https:// doi.org/10.1111/j.1540-5893.2009.00384.x

Casebeer, K. M. (2008). Of service workers, contracting out, joint employment, legal consciousness, and the university of Miami. Buffalo Law Review, 56(4), 10591093. https://doi.org/10.2139/ssrn.1020623

Chua, L.J., \& Engel, D. M. (2019). Legal Consciousness Reconsidered. In Annual Review of Law and Social Science (Vol. 15). https://doi.org/10.1146/annurev-lawsocsci-101518-042717

Chua, Lynette J., \& Engel, D. M. (2019). Legal Consciousness Reconsidered. Annual Review of Law and Social Science, 15(1), 335-353. https://doi.org/10.1146/ annurev-lawsocsci-101518-042717

Creutzfeldt, N., Mason, M., McConnachie, K., \& Creutzfeldt, N. (2019). Traditions of studying the social and the legal. Routledge Handbook of Socio-Legal Theory and Methods, 9-34. https://doi. org/10.4324/9780429952814-2

De Hart, B., \& Besselsen, E. (2020). 'Everything went according to the rules'. Female citizen sponsors' legal consciousness, intimate citizenship and family migration law. Identities. https://doi.org/10.1080/107028 9X.2020.1723310

Digregorio, N. (2016). Same-sex marriage policies and lesbian family life. Sexuality Research and So- 
cial Policy, 13(1), 58-72. https://doi.org/10.1007/ s13178-015-0211-z

DoCarmo, T., \& Rosales, R. (2019). Legal Consciousness Among Asylum Seeking Immigrants in the US: From Expectations of Fairness to Increasing Legal Cynicism Tania DoCarmo and Rocio Rosales University of California, Irvine. American Sociological Association, 1-18. https://doi.org/10.1007/978-3319-63192-9_8-1

Egorov, I. A., \& Umnyashova, I. B. (2017). Formation of Legal Consciousness in Childrenin the Context of Decentralization of Normative Regulationof Educational Organizations. Cultural-Historical PsychologyКультурно-Историческая Психология, 13(3), 16-22. https://doi.org/10.17759/chp.2017130303

Farmer, A. K., Sun, I. Y., \& Starks, B. C. (2015). Willingness to record police-public encounters: The impact of race and social and legal consciousness. Race and Justice, 5(4), 356-377. https://doi. org/10.1177/2153368715581663

Farrell-Bryan, D. (2016). Immigrant Youth, Social Identity, Instability: Legal Consciousness and the Effects of Deferred Action for Childhood Arrivals. 1-37.

Feng, Y., \& He, X. (2018). From law to politics: Petitioners' framing of disputes in Chinese courts. China Journal, 80(1), 130-149. https://doi.org/10.1086/696936

García, A. (2016). Local Laws and Undocumented Mexicans' Political Engagement: Why Immigrant Destinations Matter. 1-22.

Gleeson, S. (2010). Labor Rights for All? The Role of Undocumented Immigrant Status for Worker Claims Making. Law and Social Inquiry, 35(3), 561-602. https:// doi.org/10.1111/j.1747-4469.2010.01196.x

Gleeson, Shannon. (2010). Labor Rights for All? The Role of Undocumented Immigrant Status for Worker Claims Making. Law and Social Inquiry, 35(3), 561-602. https://doi.org/10.1111/j.1747-4469.2010.01196.x

Graca, S. (2018). Portuguese culture and legal consciousness: A discussion of immigrant women's perceptions of and reactions to domestic violence. International Journal of Law in Context, 14(3), 416-436. https://doi.org/10.1017/S1744552317000544

He, X., Wang, L., \& Su, Y. (2013). Above the roof, beneath the law: Perceived justice behind disruptive tactics of migrant wage claimants in china. Law and Society Review, 47(4), 703-738. https://doi.org/10.1111/ lasr.12043

He, Xin, Wang, L., \& Su, Y. (2013). Above the roof, beneath the law: Perceived justice behind disruptive tactics of migrant wage claimants in china. Law and So- ciety Review, 47(4), 703-738. https://doi.org/10.1111/ lasr. 12043

hHo, E. L. E., \& Chua, L. J. (2016). Law and 'race' in the citizenship spaces of Myanmar: spatial strategies and the political subjectivity of the Burmese Chinese. Ethnic and Racial Studies, 39(5), 896-916. https://doi.org/10.1 080/01419870.2015.1081963

Huang, X. (2016). Thinking on Students' Legal Education in Art Universities \& Colleges. DEStech Transactions on Social Science, Education and Human Science, icaem. https://doi.org/10.12783/dtssehs/icaem2016/4334

Khorakiwala, R. (2018). Legal Consciousness as Viewed through the Judicial Iconography of the Madras High Court. Asian Journal of Law and Society, 5(1), 111-133. https://doi.org/10.1017/als.2017.33

Kirk, E., Nicole, B., Kirk, E., \& Busby, N. (2017). Led Up the Tribunal Path? Employment Disputes, Legal Consciousness and Trust in the Protection of Law. Oñati Socio-Legal Series, 7(7), 1397-1420.

Klambauer, E. (2018). Policing roulette: Sex workers' perception of encounters with police officers in the indoor and outdoor sector in England. Criminology and Criminal Justice, 18(3), 255-272. https://doi. org/10.1177/1748895817709865

Kubal, A. (2015). Legal consciousness as a form of social remittance? Studying return migrants' everyday practices of legality in Ukraine. Migration Studies, 3(1), 68-88. https://doi.org/10.1093/migration/mnu032

Kubal, Agnieszka. (2009). Why Semi-Legal? Polish post-2004 EU Enlargement Migrants in the United Kingdom. Journal of Immigration, Asylum and Nationality Law, 23(2), 148-164.

Liu, Q. (2018). Legal Consciousness of the Leftover Woman: Law and Qing in Chinese Family Relations. Asian Journal of Law and Society, 5(1), 7-27. https:// doi.org/10.1017/als.2017.28

Ma, K. (2018). College students' legal awareness cultivation and education based on the characteristics of the new era. Kuram ve Uygulamada Egitim Bilimleri, 18(6), 3456-3462. https://doi.org/10.12738/estp.2018.6.253

Marshall, A.-M. (2005). Idle rights: Employees' rights consciousness and the construction of sexual harassment policies. Law and Society Review, 39(1), 83-124. https://doi.org/10.1111/j.00239216.2005.00078.x

Park, N. K., Kazyak, E., \& Slauson-Blevins, K. (2016). How Law Shapes Experiences of Parenthood for Same-Sex Couples. Journal of GLBT Family Studies, 12(2), 115-137. https://doi.org/10.1080/155042 $8 \times .2015 .1011818$ 
Pennington, L. (2015). A case study approach to procedural justice: Parents' views in two juvenile delinquency courts in the united states. British Journal of Criminology, 55(5), 901-920. https://doi.org/10.1093/bjc/azu109

Ryo, E. (2017). Legal Attitudes of Immigrant Detainees. Law and Society Review, 51(1), 99-131. https://doi. org/10.1111/lasr.12252

Santos, C. E., Menjívar, C., VanDaalen, R. A., Kornienko, O., Updegraff, K. A., \& Cruz, S. (2018). Awareness of Arizona's immigration law SB1070 predicts classroom behavioural problems among Latino youths during early adolescence. Ethnic and Racial Studies, 41(9), 1672-1690. https://doi.org/10.1080/ 01419870.2017 .1311021

Singer, S. (2019). "Desert Island" detention: Detainees' understandings of "Law" in the UK's Immigration detention system. Refugee Survey Quarterly, 38(1), 1-29. https://doi.org/10.1093/rsq/hdy020

Smith, A.A. (2005). Legal Consciousness and Resistance in Carribean Seasonal Agricultural Workers. Canadian Journal of Law and Society, 20(2), 95-122. https://doi.org/10.1353/jls.2006.0027

Smith, Adrian A. (2005). Legal Consciousness and Resistance in Carribean Seasonal Agricultural Workers. Canadian Journal of Law and Society, 20(2), 95-122. https://doi.org/10.1353/jls.2006.0027

Swan, R. S., \& Clark-lbáñez, M. (2017). Perceptions of Shifting Legal Ground: Daca and the Legal Consciousness of Undocumented Students and Graduates. Thomas Jefferson Law Review, 39(2),
67-92. http://scsu.idm.oclc.org/login?url=http:// search.ebscohost.com/login.aspx?direct=true\&d$\mathrm{b}=$ aph\&AN=124293169\&site=ehost-live

Tarasov, A. A. (2015). Stereotypes of Professional Legal Consciousness and the Problems of "Feedback" of Law Enforcement System and Society. Vestnik Tomskogo Gosudarstvennogo Universiteta. Pravo, 4(18(4)), 90-100. https://doi. org/10.17223/22253513/18/11

Tungohan, E. (2018). Living with Compromised Legal Status: Irregular Temporary Foreign Workers in Alberta and the Importance of Imagining, Strategizing, and Inter-Provincial Legal Consciousness. International Migration, 56(6), 207-220. https://doi.org/10.1111/ imig. 12506

Virdi, P.K. (2013). Barriers to Canadian justice: immigrant Sikh women and izzat. South Asian Diaspora, 5(1), 107-122. https://doi.org/10.1080/19438192.20 13.722383

Virdi, Preet Kaur. (2013). Barriers to Canadian justice: immigrant Sikh women and izzat. South Asian Diaspora, 5(1), 107-122. https://doi.org/10.1080/194381 92.2013 .722383

Waldrauch, H., \& Hofinger, C. (1997). An index to measure the legal obstacles to the integration of migrants. Journal of Ethnic and Migration Studies, 23(2), 271-285. https://doi.org/10.1080/1369183X.1997.9976590

Wang, H.-T. (2019). Justice, Emotion, and Belonging: Legal Consciousness in a Taiwanese Family Conflict. Law and Society Review, 53(3), 764-790. https://doi. org/10.1111/lasr.12422

\section{About the author}

\section{MIEŽANSKIENĖ RAMUNĖ}

PhD student

Kaunas University of Technology

Fields of interests

Migration, legal consciousness, legal socialization.

\section{Address}

A. Mickevičiaus g. 37, LT-44244, Kaunas, Lithuania,

Phone: +37067549775

E-mail: ramune.miezanskiene@ktu.lt 